\title{
PERUBAHAN PENGGUNAAN LAHAN PERTANIAN KE NON-PERTANIAN DALAM PERSPEKTIF SOSIAL BUDAYA
}

\author{
Oleh:
}

Rus m awan

Universitas Sanata Dharma Yogyakarta

\begin{abstract}
ABSTRAK
Lahan merupakan bagian dari bentang alam. Penggunaan lahan merupakan hasil interaksi antara faktor manusia dan faktor lahan. Manusia merupakan faktor yang mempengaruhi atau melakukan kegiatan terhadap lahan dalam usaha memenuhi kebutuhan hidupnya. Pola penggunaan lahan dipengaruhi oleh kekuatan-kekuatan dinamis yang secara garis besar dikelompokkan kekuatan centrifugal dan kekuatan centripetal. Bentuk bentang lahan, penggunaan lahan dan perkembangannya merupakan bagian dari identitas masyarakat yang hidup di dalamnya. Dampak nyata perubahan penggunaan lahan pertanian menjadi lahan non pertanian adalah semakin berkurangnya luas areal pertanian yang diikuti perubahan mata pencaharian penduduk. Pergeseran luas arel pertanian maupun mata pencaharian ini akan semakin menurunkan intensitas hubungan sosial masyarakat yang telah menjadi identitas masyarakat agraris.
\end{abstract}

Kata kunci: Penggunaan lahan, dampak sosial budaya

\section{Pendahuluan}

Secara ekologi, manusia adalah bagian integral lingkungan hidupnya. Manusia terbentuk oleh lingkungan hidupnya dan sebaliknya manusia membentuk lingkungan hidupnya. Kelangsungan hidupnya hanya mungkin dalam batas kemampuannya menyesuaikan diri terhadap perubahan dalam lingkungan hidupnya" (Otto Soemarwoto, 2001: 34). Lingkungan hidup manusia dapat digolongkan dalam beberapa kelompok yaitu lingkungan fisikal (fisical environment), lingkungan biologis (biological environment) dan lingkungan sosial (social environment)" (Bintarto dan Surastopo, 1987: 22). Sumberdaya alam akan tetap terpendam sebagai kekayaan yang potensial tidak ada manfaatnya secara nyata sebelum ada campur tangan manusia yang mampu menggali dan serta mengelolanya untuk memenuhi kebutuhan hidupnya. 
|l Perubahan Penggunaan Lahan Pertanian ke Non-Pertanian dalam Perspektif Sosial Budaya

Lahan merupakan bagian dari sumberdaya alam yang ketersediannya semakin terbatas. Manusia sebagai pengguna lahan utama jumlahnya terus meningkat seiring dengan berjalannya waktu. Hal tersebut telah mendudukkan lahan sebagai suatu komoditas penting dan strategis bagi kebutuhan manusia karena segala kegiatan di permukaan bumi ini tidak lepas dari lahan sebagai sumber daya dan ruang aktivitas.

Masalah yang dihadapi kota pada umumnya diakibatkan adanya pertambahan penduduk kota yang semakin meningkat oleh adanya pertambahan penduduk alami maupun urbanisasi. Meningkatnya pertumbuhan penduduk di perkotaan ini pada akhirnya akan menyebabkan meningkatnya kebutuhan lahan untuk berbagai kepentingan dan penggunaan. Meningkatnya kebutuhan akan lahan untuk berbagai kepentingan tersebut mengakibatkan lahan yang ada di wilayah kota seringkali menjadi ajang persaingan untuk dikuasai dan dimanfaatkan. Dampak yang timbul akibat persaingan ini adalah munculnya berbagai konflik yang berhubungan dengan masalah lahan, tingginya harga lahan terutama di lokasi-lokasi yang strategis, banyak terjadi perubahan atau pengalihan fungsi lahan yang seringkali tidak sesuai dengan potensinya. Perubahan-perubahan penggunaan lahan dapat dilihat dengan meningkatnya lahan-lahan permukiman baru maupun tempat usaha pada lahan pertanian. Dengan berkurangnya luas lahan pertanian maka penduduk yang tadinya bekerja di bidang pertanian mulai terdorong untuk melakukan kegiatan ekonomi di luar bidang pertanian.

\section{Penggunaan Lahan}

Istilah tanah memiliki tiga makna. Makna pertama menyatakan tanah adalah media alami bagi pertumbuhan tumbuh-tumbuhan. Dalam makna ini perhatiannya lebih ditekankan pada kualitas tanah. Makna kedua, tanah dipandang sebagai hancuran bahan iklim yang berasal dari batuan atau bahan organik yang diperlukan sebagai bahan galian dan bahan tambang. Dalam makna ini tanah dinyatakan dalam berat atau volume. Sedangkan makna ketiga, tanah diperlakukan sebagai ruangan atau tempat dipermukaan bumi yang digunakan oleh manusia untuk melakukan kegiatan. Dalam makna ini tanah dinilai berdasarkan luas. Kedua maka pertama ekivalen dengan kata soil dalam Bahasa Inggris, sedangkan makna ketiga lebih mendekati makna land dalam Bahasa Inggris. Istilah lahan yang dimaksudkan untuk digunakan dalam makna yang ekivalen dengan kata land tersebut.

Lahan merupakan bagian dari bentang alam (landscape) yang mencakup pengertian lingkungan fisik termasuk iklim, topografi/relief, hidrologi bahkan keadaan vegetasi alami yang semuanya secara potensial 
akan berpengaruh terhadap penggunaan lahan. Lahan dalam pengertian yang lebih luas termasuk yang telah dipengaruhi oleh berbagai aktivitas manusia baik di masa lalu maupun masa sekarang (FAO dalam PPTA, 1993 :3). Sedangkan Johara T. Jayadinata (1999: 10) mengartikan lahan sebagai tanah yang yang sudah ada peruntukannya dan umumnya sudah ada pemiliknya, baik perseorangan maupun badan-badan tertentu."Dalam hal ini lahan juga mengandung pengertian ruang atau tempat. Dengan demikian lahan mengandung makna yang lebih luas daripada tanah atau topografi" (Sitanala Aryad, 1989: 207).

Dari beberapa definisi di atas, jelaslah bahwa tanah hanyalah merupakan bagian dari lahan. Namun demikian pada kenyataannya antara keduanya seringkali digunakan secara bersamaan.

Penggunaan lahan merupakan hasil interaksi antara faktor manusia dan faktor lahan. Manusia adalah faktor yang mempengaruhi atau melakukan kegiatan terhadap lahan dalam usaha memenuhi kebutuhan hidupnya.

"Penggunaan lahan pada hahehatnya merupakan perwujudan keseluruhan kehidupan masyarakat dalam ruang" (Bintarto, 1983: 12). Ruang (space) merupakan seluruh permukaan bumi yang merupakan lapisan biosfera, tempat hidup tumbuh-tumbuhan, hewan dan manusia. Ruang permukaan bumi tiap saat unsur-unsurnya berubah karena proses alam sehingga dapat disebutkan bahwa ruang permukaan bumi itu berubah. Perubahan itu tidak ada hentinya akibat proses alam dan perbuatan manusia, maka dapat dikatakan bahwa ruang permukaan bumi itu adalah dinamis (Johara T. Jayadinata, 1999: 12).

Sitanala Arsyad (1989: 207) mengartikan penggunaan lahan sebagai setiap bentuk campur tangan manusia terhadap lahan dalam rangka memenuhi kebutuhan hidupnya baik materiil maupun spiritual. "Hampir setiap aktivitas manusia melibatkan penggunaan lahan dan karena jumlah aktivitas manusia bertambah dengan cepat, maka lahan menjadi sumber yang langka. Keputusan untuk mengubah pola penggunaan lahan mungkin memberikan keuntungan atau kerugian besar, baik ditinjau dari pengertian ekonomis, maupun terhadap perubahan lingkungan walaupun dalam keadaan yang tidak begitu nyata"(Santun R.P. Sitorus, 1985: 2).

\section{Bentuk Penggunaan Lahan}

Jangkauan pembahasan penggunaan lahan kota sangat luas karena penggunaan lahan kota sebagai suatu proses dan sekaligus produk menyangkut semua sisi kehidupan manusia" (Hadi Sabari Yunus, 2000). Penggunaan lahan yang tidak terencana seiring dengan perkembangan kota yang tidak terkendali akan menimbulkan berbagai macam permasalahan, antara lain; permasalahan perumahan, permasalahan sampah, 
|| Perubahan Penggunaan Lahan Pertanian ke Non-Pertanian dalam Perspektif Sosial Budaya

permasalahan lalu lintas, permasalahan kekurangan gedung sekolah, permasalahan terdesaknya daerah pinggiran kota (urban pheriphery) dan permasalahan administrasi pemerintah (Bintarto, 1983: 47).

Berikut ini tabulasi klasifikasi penggunaan lahan menurut Sutanto (1981: 32)

Tabel 1. Klasifikasi Penggunaan Lahan

\begin{tabular}{|c|c|c|c|}
\hline \multirow[t]{2}{*}{ No } & \multicolumn{3}{|c|}{ Klasifikasi Penggunaan Lahan } \\
\hline & Tingkat I & Tingkat II & Tingkat III \\
\hline \multirow[t]{21}{*}{1.} & \multirow[t]{21}{*}{ Daerah Kota } & \multirow[t]{2}{*}{ Permukiman } & - Permukiman Teratur \\
\hline & & & - Wisma Campuran \\
\hline & & \multirow[t]{3}{*}{ Perdagangan } & - Pasar \\
\hline & & & - Sarana Perdagangan \\
\hline & & & - Pom Bensin \\
\hline & & \multirow[t]{2}{*}{ Industri } & - Sentra Kerajinan \\
\hline & & & - Gudang \\
\hline & & \multirow[t]{2}{*}{ Transportasi } & - Jalan \\
\hline & & & - Terminal/stasiun \\
\hline & & \multirow[t]{3}{*}{ Jasa } & - Pendidikan \\
\hline & & & - Perkantoran \\
\hline & & & - Rumah Sakit \\
\hline & & \multirow[t]{2}{*}{ Rekreasi } & - Taman Kota \\
\hline & & & - Lapangan Olah Raga \\
\hline & & \multirow[t]{2}{*}{ Tempat Ibadah } & - Masjid \\
\hline & & & - Gereja \\
\hline & & \multirow[t]{3}{*}{ Pertanian } & - Sawah \\
\hline & & & - Kebun Campuran \\
\hline & & & - Tegalan \\
\hline & & \multirow[t]{2}{*}{ Lain-lain } & - Kuburan \\
\hline & & & - Lal \\
\hline
\end{tabular}

Sumber: Sutanala Arsyad (1981)

Pembangunan merupakan upaya sadar untuk mengelola dan memanfaatkan sumber daya guna meningkatkan mutu kehidupan rakyat. Pertumbuhan ekonomi yang merupakan indikator keberhasilan suatu pembangunan seringkali digunakan untuk mengukur kualitas hidup manusia., sehingga semakin tinggi nilai pertumbuhan ekonomi maka semakin tinggi pula taraf hidup manusia. Semakin cepat pertumbuhan ekonomi akan semakin banyak barang sumberdaya yang diperlukan dalam proses produksi yang pada gilirannya akan mengurangi ketersediaan sumberdaya alam sebagai bahan baku yang tersimpan pada sumberdaya 
alam yang ada. Meningkatnya jumlah penduduk secara cepat di daerah perkotan dengan segala aktivitasnya menyebabkan semakin meningkatnya kebutuhan akan lahan untuk berbagai kepentingan dan penggunaan.

Beberapa ciri karakteristik lahan di perkotan menurut Achmad Nurmandi (1999: 121)

1. Lokasi dan transportasi merupakan unsur yang sangat mempengaruhi sebidang lahan. Nilai jual sebidang lahan sangat tergantung pada aksesibilitasnya dengan jalur transportasi dan fasilitas umum. Semakin baik proksimitas (keterdekatannya) maka semakin tinggi pula nilai lahan tersebut.

2. Fungsi lahan perkotaan yang bersifat saling tergantung antara satu dengan yang lainnya. Lahan perkotaan mempunyai fungsi yang sangat kompleks. Kompleksitas fungsi ini ditunjukkan dengan banyaknya fungsi dari sebuah lahan.

3. Lahan perkotaan membutuhkan jaringan infrastruktur yang dibangun dengan dana yang sangat besar

4. Sifat lahan perkotaan sebagai barang ekonomi (economic goods) sangat kompleks. Sebidang lahan di daerah perkotaan dapat digunakan untuk tujuan hanya memiliki, atau untuk disewakan kepada pihak lain, atau untuk jaminan (borg) di bank, bagi permodalan suaatu kegiatan usaha.

5. Komoditas ekonomi, lahan merupakan sasaran spekulasi penting bagi kaum berduit. Semakin padat penduduk kota, yang diiringi dengan semakin meningkatnya kebutuhan akan lahan untuk berbagai fungsi seperti perdagangan, permukiman, infrastruktur dan lain sebagainya, pada gilirannya akan semakin melambungkan harga lahan, dan semakin dekat dengan pusat kota maka akan semakin tinggi harga lahannya

\section{Dampak Perubahan Penggunaan Lahan Terhadap Kondisi Sosial Budaya Masyarakat \\ Menurut Charles Colby (1933) dalam Hadi Sabari Yunus (2000: 177-} 178), pola penggunaan lahan kota dipengaruhi oleh kekuatan-kekuatan dinamis yang secara garis besar dikelompokkan menjadi dua. Pertama, kekuatan-kekuatan centrifugal (centrifugal forces) yaitu kekuatan dari dalam yang mengakibatkan perubahan tata guna lahan yang realisasinya berupa perpindahan penduduk yang berasal dari dalam kota menuju ke luar kota. Kedua, kekuatan-kekuatan centripetal (centripetal forces) yaitu kekuatan luar yang mengakibatkan perubahan-perubahan tataguna lahan suatu kota, yang realisasinya berupa perpindahan penduduk dari luar kota menuju ke dalam kota.

Secara umum, pembangunan tidak saja menghasilkan manfaat tetapi juga resiko. "Dampak adalah suatu perubahan yang terjadi sebagai akibat 
|l Perubahan Penggunaan Lahan Pertanian ke Non-Pertanian dalam Perspektif Sosial Budaya

suatu aktivitas" (Otto Sumarwoto, 2001: 38). Dampak perubahan penggunaan lahan diartikan sebagai suatu akibat yang timbul yang berkaitan dengan perubahan penggunaan lahan baik akibat yang timbul sesudah perubahan maupun yang menyertai perubahan penggunaan lahan meliputi gejala geosfera yang sangat luas dan komplek.

\section{Perubahan Struktur Mata Pencaharian}

Gejala pengurangan lahan sawah merupakan dampak paling nyata yang terjadi dalam perubahan penggunaan lahan. Dampak iringan dari adanya pengurangan lahan pertanian khususnya lahan sawah adalah pengurangan produksi padi sawah. Pengurangan produksi pertanian secara langsung pula akan berpengaruh pada penghasilan petani.

Sejalan dengan perubahan bentuk penggunaan lahan pertanian dan luasnya dari tahun ke tahun adalah wajar apabila penduduk yang bertahan dalam kegiatan pertanian juga mengalami perubahan. Oleh karena salah satu penyebab berubahnya bentuk perubahan penggunaan lahan pertanian menjadi lahan non pertanian adalah makin banyaknya penduduk ataupun institusi yang mendirikan bangunan pada lahan-lahan pertanian maka adalah wajar apabila penduduk yang berkegiatan di luar pertanian juga mengalami perubahan.

a. Status Penguasaan Lahan Sawah

Status penguasaan lahan sawah yang meliputi lahan sawah yang status milik sendiri, sewa dan sakap sangat mempengaruhi tingkat pendapatan dari usaha tani. Secara keseluruhan status pemilikan lahan sawah mengalami penurunan dengan adanya perubahan penggunaan lahan.

b. Pergeseran Mata Pencaharian

Pergeseran mata pencaharian adalah bergesernya pekerjaan pokok seseorang yang disebabkan oleh pengaruh lingkungan. Pergeseran mata pencaharian karena lahan sawah yang mereka miliki telah berubah menjadi lahan permukiman maupun lahan perdagangan sehingga penduduk yang semula bekerja di bidang pertanian beralih ke jenis pekerjaan lain selain pertanian. Umumnya penduduk yang beralih pekerjaan terletak di pinggir jalan utama dengan memanfaatakan rumahnya sebagai tempat tinggal sekaligus sebagai tempat usaha.

\section{Menurunnya intensitas hubungan sosial masyarakat}

Pengambilan keputusan masyarakat petani dalam pengalihfungsian penggunaan lahan dari lahan pertanian ke lahan non pertanian tidak selalu didasarkan kepada pertimbangan finansial, ada faktor-faktor sosial budaya yang mendorong masyarakat untuk mengalihfungsikan lahan pertanian 
mereka antaranya adalah adanya rasa kebanggaan apabila seseorang mengikuti laju pembangunan dewasa ini.

Bentuk bentang lahan, penggunaan lahan dan perkembangannya merupakan bagian dari identitas masyarakat yang hidup di dalamnya. Petani biasanya memiliki kebutuhan yang kuat untuk memihak pada budaya setempat. Sejarah dan tradisi memainkan peranan penting dalam kehidupan, cara dan sistem penggunaan lahan mereka. Perubahan yang tidak selaras dengan nilai-nilai sosial, budaya, spiritual mereka, bisa menyebabkan stress dan menciptakan kekuatan yang berlawanan. Kemampuan untuk memperoleh kehidupan yang layak (termasuk mewariskan sesuatu kepada anak cucu) dan sesuai dengan budaya setempat akan memberikan rasa harga diri pada individu atau keluarga. Identitas suatu keluarga petani atau komunitas dipertahankan dengan teknologi yang memungkinkan mereka menjadi mandiri dan mampu mengendalikan pengambilan keputusan atas pemanfaatan sumber daya dan produk setempat

Sistem penguasaan lahan pertanian mengandung aspek hubungan sosial. Hubungan sosial itu dapat berupa hubungan kerja atau bagi hasil antara pemilik lahan pertanian dengan buruh tani, hubungan sewa atau gadai antara pemilik lahan dengan penyewa atau penggadai lahan, hubungan kontrak lahan antara pemilik lahan dengan pemilik modal yang mengkontrak lahan untuk pemanfaatan lahan pertanian. Hubungan sosial itu menunjukkan posisi-posisi dan kekuasaan-kekuasaan orang-orang (pihak-pihak) yang terlibat. Pihak yang memegang kekuasaan lebih besar terhadap lahan akan menentukan pola hubungan tersebut dan menentukan sistem pemanfaatan lahan pertanian yang dikembangkan. Adanya perkembangan sosial ekonomi menyebabkan hubungan-hubungan sosial berkembang dan aturan penguasaan lahan pertanian semakin kompleks. Misalnya di pedesaan Jawa sudah lama berkembang sistem sewa, gadai, bagi hasil sehingga hak atas lahan dapat terpisah dari hak atas tanaman.

Intensitas hubungan sosial kemasyarakatan terkait dengan pemanfaatan lahan pertanian seperti di atas tentu saja akan semakin berkurang sejalan dengan semakin berkurangnya luas lahan pertanian.

\section{Penutup}

Gejala pengurangan lahan sawah merupakan dampak paling nyata yang terjadi akibat perubahan penggunaan lahan dari lahan pertanian menjadi lahan non pertanian. Sejalan dengan perubahan bentuk penggunaan lahan pertanian dan luasnya dari tahun ke tahun penduduk yang bertahan dalam kegiatan pertanian juga mengalami perubahan. Dampak jangka panjang 
|| Perubahan Penggunaan Lahan Pertanian ke Non-Pertanian dalam Perspektif Sosial Budaya

akan terlihat pada menurunnya intensitas hubungan sosial kemasyarakatan terkait dengan pemanfaatan lahan pertanian.

\section{Daftar Pustaka}

Achmad Nurmandi. (1999). Manajeman Perkotaan Aktor, Organisasi dan Pengelolaan Daerah Perkotaan di Indonesia. Yogyakarta: Lingkaran Bangsa.

Bintarto dan Surastopo. (1987). Metode Analisa Geografi. Jakarta: LP3ES

Bintarto. (1989). Interaksi Desa-Kota dan Permasalahannya. Jakarta: Ghalia Indonesia.

Branch, Melvile C. (1995). Comprehensive City Planning: Introduction \& Explanation (Bambang Hadi Wibisono). Terjemahan. Chicago: American Planning Assotiation. Buku asli di terbitkan tahun 1985.

Hadi Sabari Yunus. (2000). Struktur Tata Ruang Kota. Yogyakarta: Pustaka Pelajar.

. (2001)."Perubahan Pemanfaatan Lahan di Daerah Pinggiran Kota: Studi Kasus di Pinggiran Kota Yogyakarta". Disertasi. Yogyakarta: Fakultas Geografi UGM.

Hari Kartono, Sugeng Raharjo \& I Made Sandy. (1998). Esensi Pembangunan Wilayah dan Penggunaan Tanah Berencana. Jakarta: Penerbit Geografi FMIPA-UI

Ida Bagus Mantra. (1985). Pengantar Studi Geografi. Yogyakarta: Nur Cahaya.

Ilhami. (1988). Strategi Pembangunan Perkotaan di Indonesia. Surabaya: Usaha Nasional.

Johara T. Jayadinata. (1999). Tata Guna Tanah dalam Perencanaan Perdesaan, Perkotaan dan Wilayah. Bandung: Penerbit ITB.

Tambunan, T.T.H. 1996. Perekonomian Indonesia. Jakarta: Ghalia Indonesia 